\title{
Quantitative Determination of Trans-Fatty Acids in Oils and Fats by Capillary Gas Chromatogra- phy: Results of a JOCS Collaborative Study
}

\author{
Seiichi Shirasawa ${ }^{*}$, Makoto Shiota ${ }^{2}$, Hiroshi Arakawa ${ }^{3}$, Yasuhiko Shigematsu ${ }^{4}$, \\ Kazuhisa Yokomizo ${ }^{5}$, Noriko Shionoya ${ }^{6}$, Takahisa Okamoto ${ }^{7}$, Yousuke Miyazaki ${ }^{8}$, \\ Shigeyuki Takahashi ${ }^{9}$ and Katsuichi Himata ${ }^{10}$ \\ ${ }^{1}$ The Nisshin OilliO Group, Ltd. (1-Banchi, Shinmei-cho, Yokosuka, Kanagawa 239-0832, JAPAN) \\ ${ }^{2}$ Snow Brand Milk Products Co., Ltd. (1-1-2, Minami-dai, Kawagoe, Saitama 350-1165, JAPAN) \\ ${ }^{3}$ ADEKA CORPORATION (7-2-34, Higashi-Oku, Arakawa-ku, Tokyo 116-8553, JAPAN) \\ ${ }^{4}$ Q.P. Corporation (5-13-1, Sumiyoshi-cho, Fuchuu, Tokyo 183-0034, JAPAN) \\ ${ }^{5}$ J-OIL MILLS, INC. (8-1, Akashi-cho, Chuo-ku, Tokyo 104-0044, JAPAN) \\ ${ }^{6}$ Japan Food Research Laboratories (4-5-13, Oozu, Naka-ku, Nagoya 460-0011, JAPAN) \\ 7 Japan Institute for Oils and Fats and Other foods Inspection (3-27-8, Nihonbashi-Hamacho, Chuo-ku, Tokyo 103-0007, JAPAN) \\ ${ }^{8}$ NOF CORPORATION (3-3, Chidori-cho, Kawasaki-ku, Kawasaki, 210-0865, JAPAN) \\ ${ }^{9}$ NIPPON YURYO KENTEI KYOKAI (5-26-1, Kaigan-doori, Naka-ku, Yokohama 231-0002, JAPAN) \\ ${ }^{10}$ YAMAZAKI BAKING CO., LTD (3-15-6, Chitose, Sumida-ku, Tokyo 130-0025, JAPAN)
}

\begin{abstract}
Excessive intake of trans-fatty acids increases the risk of cardiovascular disease. Much attention is drawn to the consumption of trans-fatty acids worldwide, and regulations for trans-fatty acids are instituted in several countries.

Precise and convenient methods for determination of trans-fatty acid level are required, but there is no standard method using capillary Gas Chromatography in Japan. Therefore, for the new standard method, collaborative studies were carried out.

The results were as follows:

1) Heptadecanoate (C17:0 free fatty acid) was chosen for internal standard substance.

2) Two Gas Chromatography columns, SP2560 (100 m) column (100\% cyanopropyl polysiloxane liquid phase) and TC-70 $(60 \mathrm{~m})$ column (70\% cyanopropyl polysilphenylene-siloxane liquid phase), were examined in the collaborative studies. We measured the edible oil samples containing 2-45 $\mathrm{g} / 100 \mathrm{~g}$ of transfatty acids, and trans-fatty acid contents were quantitatively the same with both columns. The range of reproducibility coefficient of variation were below $10 \%$.

3) Fats and oils sampled were soybean, rapeseed, palm, palm kernel, beef tallow, pork fat and their hydrogenated forms, for which good peak resolution was achieved.

From the above results, the technique evaluated in the present study was considered to be suitable for determination of the content of trans-fatty acids in fats and oils exclusive of fish oil and milk fat.
\end{abstract}

Key words: trans-fatty acid, fatty acid analysis, capillary column, gas chromatography

$$
\begin{aligned}
& 1 \text { 緒言 } \\
& \text { トランス脂肪酸は, LDL コレステロールを増加させ, }
\end{aligned}
$$

HDL コレステロールを減少させる働きがあるといわれ ている1)。また，多量のトランス脂肪酸の撕取が動脈硬 化などによる心疾患などの発症リスクを高める可能性

\footnotetext{
* Correspondence to: Seiichi Shirasawa, Standards and Analyses, Central Research Laboratory, The Nisshin OilliO Group, Ltd., 1-Banchi, Shinmei-cho, Yokosuka, Kanagawa 239-0832, JAPAN

E-mail: s-shirasawa@nisshin-oillio.com
}

Accepted May 22, 2007 (received for review April 2, 2007)

Journal of Oleo Science ISSN 1345-8957 print / ISSN 1347-3352 online

http://jos.jstage.jst.go.jp/en/ 
があるとされ ${ }^{2)}$ ，トランス脂肪酸摂取の多い各国ではト ランス脂肪酸量の表示義務化も行われている ${ }^{3-5)}$ 。日本 国内に打いては, 内閣府食品安全委員会がファクト シートを発行した ${ }^{6)}$ などの動きがあるが, 現状規制の 動きはない。しかし, このような状況を受けて, トラ ンス脂肪酸の簡便・正確な分析法の需要が高まってい る。トランス脂肪酸分析法としては, 赤外吸収 (IR), HPLC，ガスクロマトグラフィー（GC）などがあるが， 分析精度 ・簡便性の点から脂肪酸メチルエステルの GC 分離によりトランス脂肪酸を定量する直接 GC 法が主 流となりつつある。しかし, 日本の基準油脂試験法に は, IR 法と, 硝酸銀 TLC 分画- GC 法が収載されてい るが, 直接 GC 法は存在していない。そこで, 直接 GC 法により，簡便にモノエン，ジエン，トリエン型のト ランス脂肪酸を定量可能な試験方法を, 合同実験を踏 まえて設定することとなった。

合同実験は以下の前提で実施した：

・油脂中のトランス脂肪酸含量測定法の設定であり,

食品からの抽出は範囲に含まない。

・乳脂, 魚油はトランス脂肪酸組成が複雑なため, 適用範囲から除外する。

・国際的な各種ガスクロマトグラフ法 ${ }^{7-9)}$ を参考にす る。

・キャピラリーカラムを用いた，メチルエステル体

の直接 GC 法による分析とする。

・内部標準物質を用いた, 遊離脂肪酸換算による定 量分析とする。

・試験法に打ける装置・器具の限定を出来る限り避

けるために, カラム液相扣よび長さについて幅を持
たせた実験設定を行う。

・幅広いトランス脂肪酸含量範囲の試験サンプルを 用いた検討を行う。

\section{2 実験}

\section{$2 \cdot 1$ 試料，標準品及び試薬}

$2 \cdot 1 \cdot 1$ 試 薬

定量標準物質として検討に用いたへプタデカン酸 (C17：0FFA）は東京化成工業(株)製のものを, ヘネイ コサン酸（C21：0FFA）は Sigma 製のものを用いた。 定性・分離確認用混合試薬として, SP-2560 評価用 FAME Mix（Supelco 製：製品番号 47088-U）を用いた。 これらの試薬は合同実験参加全機関で同一ロットのも のを使用した。

$2 \cdot 1 \cdot 2$ 試料油脂およびその調製

大豆油，大豆水素添加油，なたね油，なたね水素添 加油は日清オイリオグループ(株)が提供したものを用 い, 大豆油打よび大豆水素添加油，なたね油およびな たね水素添加油をそれぞれ $1: 0,20: 1,10: 1,5: 1$, $0: 1$ (いずれも $\mathrm{w} / \mathrm{w})$ に取りまとめ機関が調製した。 調製サンプルは内容を示さずに参加機関に送付し，実 験に供した。牛脂, 豚脂, パーム核油, 抢よびこれら の水素添加油は日本油脂 (株)が, パーム油およびパー ム水素添加油は (株) ADEKA が提供したものを用いた。 サンプルの送付および各参加機関での保管は冷蔵条件 (約 $4{ }^{\circ} \mathrm{C}$ ) で行った。これら試料油脂の基本分析值を Table 1 に示す。

Table 1 Samples Used for the Collaborative Study.

\begin{tabular}{|c|c|c|c|c|}
\hline & Soybean & $\begin{array}{l}\text { Hydrogenated } \\
\text { soybean }\end{array}$ & Rapeseed & $\begin{array}{c}\text { Hydrogenated } \\
\text { rapeseed }\end{array}$ \\
\hline POV & 0.60 & 0.63 & 0.48 & 0.43 \\
\hline $\mathrm{AV}$ & 0.06 & 0.05 & 0.06 & 0.06 \\
\hline \multirow[t]{2}{*}{ IV } & - & 72 & - & 74 \\
\hline & Beef tallow & $\begin{array}{c}\text { Hydrogenated } \\
\text { beef tallow }\end{array}$ & Pork fat & $\begin{array}{c}\text { Hydrogenated } \\
\text { pork fat }\end{array}$ \\
\hline IV & 48 & 39 & 60 & 43 \\
\hline \multirow[t]{2}{*}{ m.p. } & 41 & 48 & 38 & 48 \\
\hline & Palm kernel & $\begin{array}{l}\text { Hydrogenated } \\
\text { palm kernel }\end{array}$ & Palm & $\begin{array}{c}\text { Hydrogenated } \\
\text { palm }\end{array}$ \\
\hline IV & 18 & 13 & 51 & 40 \\
\hline m.p. & 27 & 29 & 36 & 45 \\
\hline
\end{tabular}




\section{$2 \cdot 2$ 装置および条件}

参加各機関が実験に用いたガスクロマトグラフ装置 を Table 2 に示す。

キャピラリーカラムは以下の 2 種類を用いた。実験 に際しては, 参加全機関で同一液相ロットの製品を使 用した。

·SP-2560（Supelco 製）カラム長 $100 \mathrm{~m}$, 内径 $\phi 0.25$ $\mathrm{mm}$, 膜厚 $0.20 \mu \mathrm{m}$

· TC-70（ジーエルサイエンス製）カラム長 $60 \mathrm{~m}$, 内 径 $\phi 0.25 \mathrm{~mm}$, 膜厚 $0.25 \mu \mathrm{m}$

ガスクロマトグラフ条件は, 事前に取りまとめ機関 が設定し，各機関同一条件にて実施した。それぞれの カラムを用いた場合のガスクロマトグラフ条件を Table 3 に, 得られたクロマトグラム例を Fig. 1 に示す。

Table 2 Gas Chromatographic Equipments Used by Collaborators.

\begin{tabular}{clc}
\hline Laboratory & Gas Chromatography & Auto Injector \\
\hline A & HP6890 (Agilent) & equipped \\
B & HP5890 II (Agilent) & equipped \\
C & HP5890 (Agilent) & equipped \\
D & HP5890 II (Agilent) & equipped \\
E & HP6890 (Agilent) & equipped \\
F & GC-2010 (Shimadzu) & equipped \\
G & GC-17A (Shimadzu) & none \\
H & HP5890 (Agilent) & equipped \\
J & GC-2010AF (Shimadzu) & equipped \\
K & HP5890 II (Agilent) & equipped \\
L & GC-17A (Shimadzu) & none \\
\hline
\end{tabular}

\section{$2 \cdot 3$ 操 作}

メチルエステル化は基準油脂分析試験法 2.4.1.2 ${ }_{-1996}$ 三フッ化ホウ素メタノール法10)により実施した。メチ ルエステル化の際, 装置や器具の限定は行わなかった。 内部標準物質は試料油脂の約 10\%（w/w）の添加量と し, 試料油脂と同時にメチルエステル化を行った。ガ スクロマトグラフへの負荷量を一定とするため， ガス クロマトグラフ注入時の試料濃度を約 $1 \%$ と規定した。 以下に操作を示す。内部標準物質 $2 \sim 5 \mathrm{mg}$ と試料油脂 20 〜 $5 \mathrm{mg}$ を同一容器に精秤した。 $0.5 \mathrm{~mol} / \mathrm{L}$ 水酸化 ナトリウムーメタノール溶液 $1 \mathrm{~mL}$ を加え, 油滴が消失 するまで約 $100^{\circ} \mathrm{C}$ で 5 ～ 10 分加熱した。放冷後 $14 \%$ 三 フッ化ホウ素メタノール溶液 $1 \mathrm{~mL}$ を加え, 再度約 $100^{\circ} \mathrm{C}$ で 5 分加熱した。放冷後, 試料濃度が約 $1 \%$ にな るようにへキサン 2 〜 $\mathrm{mL}$ を加え, これに飽和食塩水 を加え振とうした。へキサン層を採り, 少量の無水硫 酸ナトリウムで脱水し，ガスクロマトグラフ用試料溶 液とした。

各試料につき，以上の操作を合同実験ごとに所定の $\mathrm{n}$ 数で実施し, Table 3 の条件で GC に供した。

クロマトグラム中のトランス脂肪酸の同定は, 事前 に取りまとめ機関が所定の GC 条件にて確認したクロ マトグラム中の対象トランス酸の相対保持時間を参照 することで行った。参照クロマトグラムのピーク同定 に関しては, 市販定性用試薬（リノール酸メチルエス テル Mix：製品番号 47791, リノレン酸メチルエステル Mix：製品番号 47792，いずれも Supelco 製）および硝 酸銀 TLC で分画した大豆水素添加油メチルエステルと の溶出時間比較と GC-MS 分析を併用することにより決

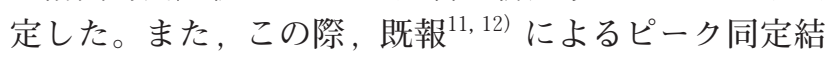
果を参照した。

Table 3 Gas Chromatography Conditions Used in the Experiments.

\begin{tabular}{lcc} 
& Method a & Method b \\
\hline Column & SP-2560 (Supelco Inc.) & TC-70 (GL-Science) \\
Stationary phase & $100 \%$ cyanopropyl polysiloxane & $70 \%$ cyanopropyl polysilphenylene-siloxane \\
Length & $100 \mathrm{~m}$ & $60 \mathrm{~m}$ \\
Internal diameter & $0.25 \mathrm{~mm}$ & $0.25 \mathrm{~mm}$ \\
Film thickness & $0.20 \mu \mathrm{m}$ & $0.25 \mu \mathrm{m}$ \\
Temperature & $180^{\circ} \mathrm{C}^{1)}$ & $190^{\circ} \mathrm{C}$ \\
Inj/Det & $250^{\circ} \mathrm{C} / 250^{\circ} \mathrm{C}$ & $250^{\circ} \mathrm{C} / 260^{\circ} \mathrm{C}$ \\
Carrier gas & $1 \mathrm{~mL} / \mathrm{min}^{\circ}(\mathrm{Helium})$ & $1 \mathrm{~mL} / \mathrm{min}(\mathrm{Helium})$ \\
Split ratio & $100: 1$ & $100: 1$ \\
Inject volume & $1 \mu \mathrm{L}$ & $1 \mu \mathrm{L}$ \\
\hline
\end{tabular}

${ }^{1)} 180^{\circ} \mathrm{C}(60 \mathrm{~min})-\left(10^{\circ} \mathrm{C} / \mathrm{min}\right)-220^{\circ} \mathrm{C} 10 \mathrm{~min}$

2) $1 \%$ sample solution in hexane 


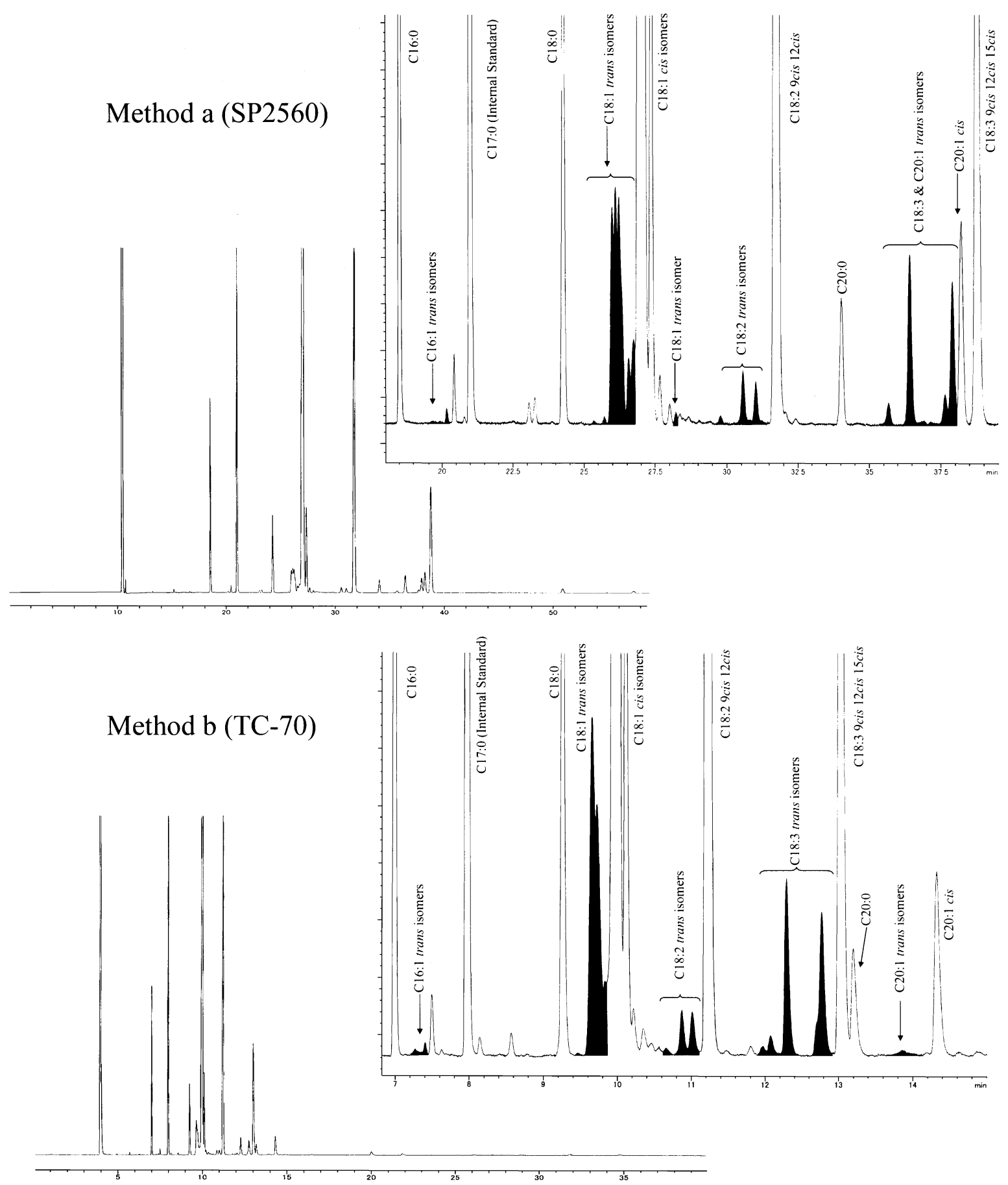

Fig. 1 GC Chromatograms.

Sample : Mixture of Rapeseed Oil and Hydrogenated Rapeseed Oil (10:1, w/w).

\section{$2 \cdot 4$ 含量計算・統計処理}

取りまとめ機関が事前に配布したクロマトグラムを 参照し, C16:1, C18:1, C18:2, C18:3, C20:1 の各トランス脂肪酸ピークを選び出し, データ処理装 置によりそのピーク面積值を算出した。これを下記計
算式に適用し，含量を小数点以下第 2 位まで算出した。 <計算式 $>$

(1)内部標準補正あり（内部標準としてへプタデカン 酸を用いた場合）

トランス脂肪酸含量 $(\mathrm{g} / 100 \mathrm{~g})=\mathrm{A} \times \mathrm{E} \times \mathrm{F} /$ 
$(\mathrm{A} \times \mathrm{D}-\mathrm{B} \times \mathrm{C}) / \mathrm{G} \times 100$

(2)内部標準補正なし

トランス脂肪酸含量 $(\mathrm{g} / 100 \mathrm{~g})=\mathrm{E} \times \mathrm{F} / \mathrm{D} /$

$\mathrm{G} \times 100$

(3)組成計算

トランス脂肪酸含量 $(\%)=\mathrm{H} / \mathrm{J} \times 100$

但し，記号は以下を表す

$\mathrm{A}$ ：内部標準無添加クロマトグラムのパルミチ ン酸のピーク面積

$\mathrm{B}$ ：内部標準無添加クロマトグラムのへプタデ カン酸溶出位置に現れたピーク面積

$\mathrm{C}$ ：内部標準添加クロマトグラムのパルミチン 酸のピーク面積

$\mathrm{D}$ ：内部標準添加クロマトグラムの内部標準物 質のピーク面積

$\mathrm{E}$ ：内部標準添加クロマトグラムの各分子種卜 ランス脂肪酸ピーク面積值の合計

$\mathrm{F}$ : 内部標準物質添加量 $(\mathrm{mg})$

$\mathrm{G}$ : 試料採取量 $(\mathrm{mg})$

$\mathrm{H}$ ：内部標準無添加クロマトグラムの各分子種 トランス脂肪酸ピーク面積值の合計

$\mathrm{J}$ ：内部標準無添加クロマトグラム中の溶剤 ピークを除いた全ピーク面積合計值

統計処理として, 基準油脂試験法 ${ }^{13)}$ を参考に, Cochran 検定抢よび，Dixon 検定を行った。

\section{3 実 験 結果}

\section{$3 \cdot 1$ 合同実験 1 （予備実験）}

米国でのトランス脂肪酸表示義務化 ${ }^{3)}$ にともない, AOCS のトランス脂肪酸分析試験法が改訂された ${ }^{8)}$ 。本 法はトランス脂肪酸と他の脂肪酸との高分離が期待で きるため，まず本法に準じた実験を行った。ただし， 内部標準物質については変更を行うこととした。改訂
AOCS 法 ${ }^{8)}$ で用いている内部標準物質はトリヘネイコ サノイン（Tri C21：0）である。改訂 AOCS 法は, ト ランス脂肪酸のみではなく, 総脂質等も算出する手法 であること, C21：0 は通常の油脂においてはほとんど 検出されないことから本物質が採用されたと考えられ るが，トランス脂肪酸を遊離脂肪酸換算で算出する際 には，標準物質も遊離脂肪酸体であれば換算係数が不 要であること, トリへネイコサノイン試薬が高価であ り, かつ生産量が少ないため合同実験に供する量が確 保できないことから，ヘネイコサン酸（C21：0 遊離脂 肪酸）を内部標準物質とすることとした。油脂中のト ランス脂肪酸はトリグリセリド体で存在して打り，こ の観点からは標準物質もトリグリセリド体である方が 望ましいが, 遊離・エステル体を問わずメチルエステ ル化可能な三フッ化ホウ素メタノール法を前処理に採 用することで，問題は無いと判断した。

合同実験 1 は大豆油打よび大豆水素添加油，なたね 油打よびなたね水素添加油，それらの混合サンプル計 10 サンプルを用い, 11 機関で実施した。キャピラリー カラムおよび内部標準物質へネイコサン酸は全機関で 同一ロットのものを使用した。各機関において，内部 標準添加を 2 連でサンプル調製し，Table 3 中の Method aのガスクロマトグラフ条件にて分析を行っ た。Table 4 に検定後統計処理結果を示す。この検討に おいては，とくにトランス含量低位のサンプルについ て, 再現相関係数 $\left(\mathrm{CV}_{\mathrm{R}}\right)$ が大きい結果となっている。 この要因として, 内部標準物質の秤量法を統一してい なかった点が考えられたため, これ以降の実験では， 内部標準物質は有機溶剤で定溶して測り採る方式に統 一することとした。

\section{$3 \cdot 2$ 標準物質の選択}

合同実験 1 で得られたクロマトグラムに溶出した全 ピークを用いて，総脂肪酸量を測定すると $100 \mathrm{~g} / 100 \mathrm{~g}$

Table 4 The Results of the Statistical Analysis (1st. Collaborative Experiment).

\begin{tabular}{lccccccccccc}
\hline \multicolumn{1}{c}{ Sample } & \multicolumn{3}{c}{ Soybean / Hydrogenated Soybean $(\mathrm{w} / \mathrm{w})$} & \multicolumn{6}{c}{ Rapeseed / Hydrogenated Rapeseed (w/w) } \\
& $1: 0$ & $20: 1$ & $10: 1$ & $5: 1$ & $0: 1$ & $1: 0$ & $20: 1$ & $10: 1$ & $5: 1$ & $0: 1$ \\
\hline Total number of laboratories in a given assay & 11 & 10 & 10 & 11 & 11 & 11 & 10 & 11 & 11 & 9 \\
Total number of values in a given assay & 22 & 20 & 20 & 22 & 22 & 22 & 20 & 22 & 22 & 18 \\
Mean & 2.6 & 4.2 & 6.1 & 9.1 & 44.9 & 2.9 & 5.2 & 6.9 & 10.4 & 52.0 \\
Repeatability standard deviation (Sr) & 0.297 & 0.103 & 0.202 & 0.277 & 0.807 & 0.113 & 0.217 & 0.481 & 0.451 & 0.802 \\
Repeatability coefficient of variation $(\mathrm{CVr})$ & 11.384 & 2.435 & 3.298 & 3.025 & 1.798 & 3.915 & 4.174 & 7.016 & 4.353 & 1.542 \\
Reproducibility standard deviation $\left(\mathrm{S}_{\mathrm{R}}\right)$ & 0.35 & 0.72 & 0.81 & 1.13 & 3.57 & 0.41 & 0.74 & 1.24 & 1.29 & 1.82 \\
Reproducibility coefficient of variation $\left(\mathrm{CV}_{\mathrm{R}}\right)$ & 13.59 & 17.17 & 13.21 & 12.34 & 7.95 & 14.18 & 14.21 & 18.12 & 12.48 & 3.49 \\
Repeatability value (r) & 0.84 & 0.29 & 0.57 & 0.78 & 2.28 & 0.32 & 0.62 & 1.36 & 1.28 & 2.27 \\
Reproducibility value (R) & 1.00 & 2.05 & 2.29 & 3.19 & 10.10 & 1.16 & 2.09 & 3.52 & 3.66 & 5.14 \\
\hline
\end{tabular}



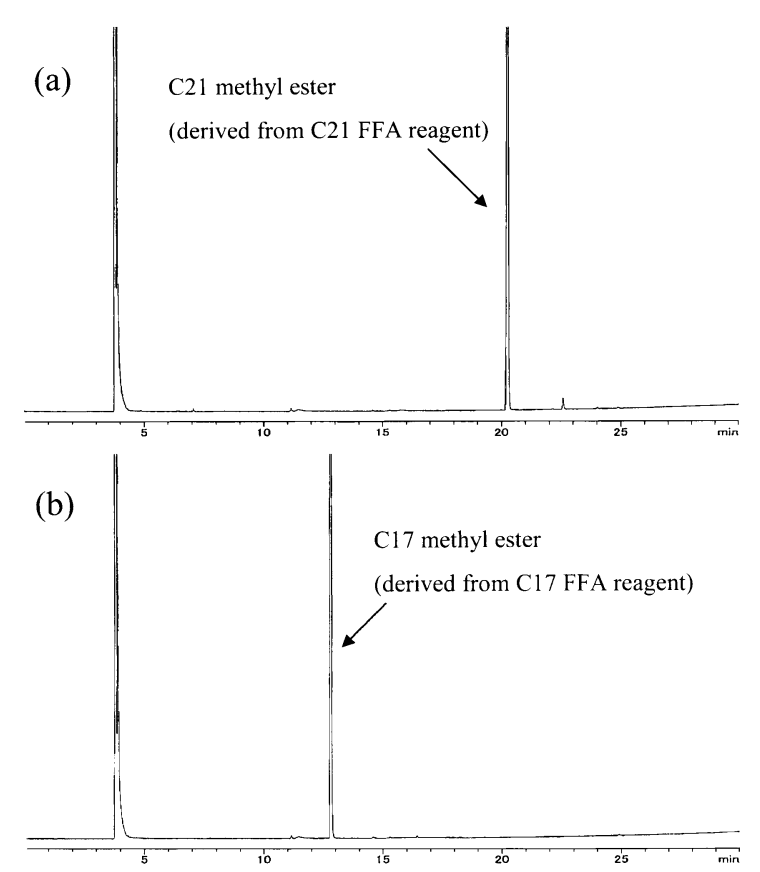
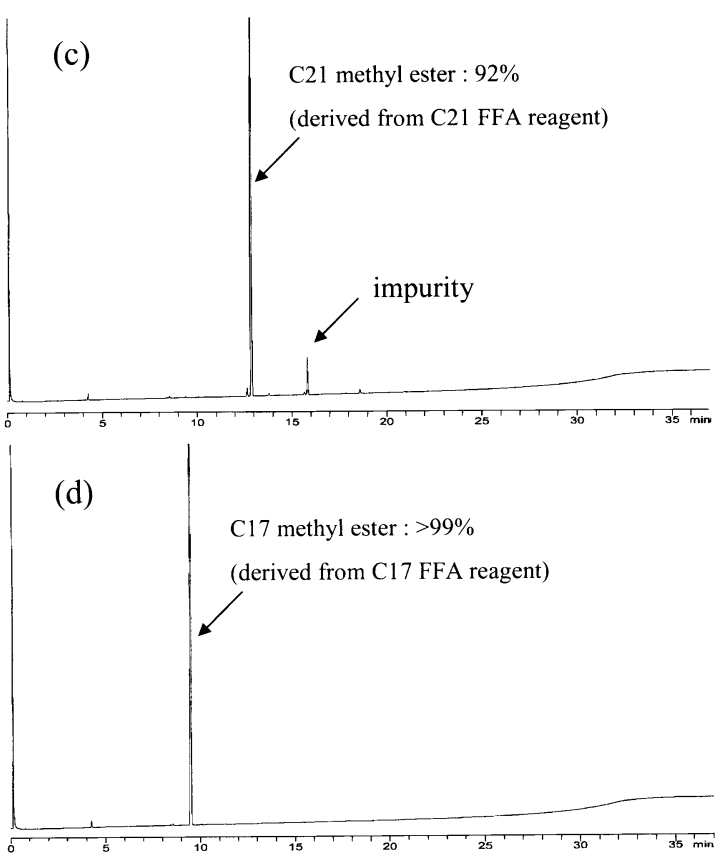

Fig. 2 Chromatograms of C21:0 FFA and C17:0 FFA Reagents' Methylester. GC Condition :

(a) \&(b) :TC-70 $(\phi 0.25 \times 60 \mathrm{~m} \times 0.25 \mu \mathrm{m})$ column, oven temp. $150^{\circ} \mathrm{C} \rightarrow 3^{\circ} \mathrm{C} / \mathrm{min} . \rightarrow 240^{\circ} \mathrm{C}$

(c) \&(d) : DB-1ht $(\phi 0.32 \times 5 \mathrm{~m} \times 0.1 \mu \mathrm{m})$ column, oven temp. $50^{\circ} \mathrm{C} \rightarrow 10^{\circ} \mathrm{C} / \mathrm{min} . \rightarrow 370^{\circ} \mathrm{C}(10 \mathrm{~min}$. hold).

を超える值が算出され, 試薬純度について疑問が呈さ れた。そこで内部標準物質の純度確認を GC 法および 中和価測定により検討した。GC 法の結果を Fig. 2 に示 す。合同実験 1 に用いた試薬へネイコサン酸をメチル エステル化し, 脂肪酸分析に用いる高極性カラムに導 入したところ, Fig. 2a のように他の脂肪酸種はほとん ど確認されなかったが，このメチルエステルを高沸点 まで分析可能な無極性カラムに導入したところ, Fig. 2c に示すようにクロマトグラムの高沸点部に不明ピー クが確認され，C21：0メチルエステルの面積值は $92 \%$ と算出された。本試薬の中和価測定も試みたが, 溶剤 に溶けにくく, 安定した数值が算出されなかった。

合同実験実施時点において, ヘネイコサン酸試薬は, 合同実験 1 に用いた製造元のものしか入手ルートが確 認出来なかった。そこで, 他の試薬を標準物質として 検討することとし, 厚生労働省による食事損取基準算 出にも用いられているへプタデカン酸 $(\mathrm{C} 17: 0$ 遊離脂 肪酸）を検討することとした。試薬へプタデカン酸を メチルエステル化して得られたクロマトグラムを Fig. 2b および Fig. 2d に示す。いずれの GC 条件に打いても 良好な結果が得られた。試薬へプタデカン酸について は, 中和価の測定結果が 209.8（2 連測定の平均值）と 算出され，理論值 207.45 から計算上の純度が $101.1 \%$ と 算出された。以上二つの手法で十分な純度であると判

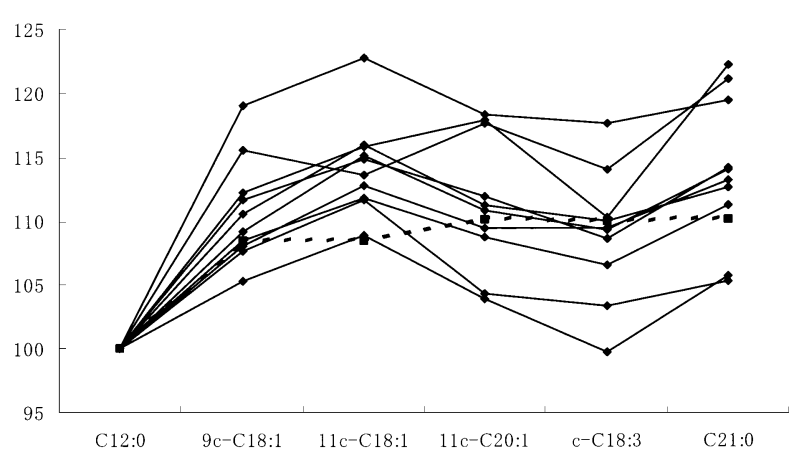

Fig. 3 Relative FID Sensitivity of Equal Amounts of the Methylesters as C12:0 Area for 100.

断されたため, 以後の実験はへプタデカン酸を標準物 質として検討することとした。

\section{$3 \cdot 3$ FID 感度補正の検討}

改訂 AOCS 法 ${ }^{8)}$ に扔いては，ガスクロマトグラフに より得られた各ピークについて, 理論 FID 感度を用い て補正を行うこととしている。感度補正の基準油脂試 験法に打ける必要性を検討するために, 混合メチルエ ステル試薬を Table 3 中の Method a のガスクロマトグ ラフ条件にて分析を行い, 各ピークの相対面積值を求 めた。Fig. 3 に $12 ： 0$ を基準にした相対感度を四示し 
た。使用した混合試薬（SP-2560 評価用 FAME Mix） は, $\mathrm{C} 12 ： 0,9 c-\mathrm{C} 18: 1,11 c-\mathrm{C} 18: 1,11 c-\mathrm{C} 20: 1, c-$ C18：3, C21：0 のメチルエステルを等量ずつ含み, 理 論 FID 感度は点線のように表されるが，各機関の実測 值から算出した感度は, 実線のように広く分布した。 この結果から，FID 感度は装置の状態等により一定で はないと確認がなされた。分析対象であるトランス脂 肪酸の主な構成成分は $\mathrm{C} 18$ だが, 今回の検討において は, $\mathrm{C} 17$ もしくは C21 脂肪酸を内部標準物質に設定し ており，標準物質と分析対象の感度差がそもそも大き くないことも踏まえ, 含量算出において, 理論值によ る補正の採用は見送ることとした。

\section{$3 \cdot 4$ 合同実験 2}

ヘプタデカン酸標準を用い, 合同実験 1 と同様の条 件で再度実験を行った (10 機関)。サンプルとしては， 合同実験 1 に用いたサンプルのうち，なたね油となた ね水素添加油, およびその混合サンプルの計 5 点とし た。合同実験 1 の結果を踏まえ, 定量標準は, 有機溶 鼡（クロロホルム）溶解により添加する形に統一した。 ガスクロマトグラフ条件は, 合同実験 1 と同様 Table 3 中の Method a の条件とした。へプタデカン酸は多くの 油脂で微量ながら存在が確認されるため, 合同実験 2 に扎いては, 内部標準添加を 2 連で, 内部標準無添加
を 1 連でデータ取得を行い, 定量標準の補正の有無そ れぞれを算出することとした。また，本実験では内部 標準無添加のクロマトグラムから脂肪酸組成を算出し, トランス脂肪酸を組成\%で算出する手法も併せて検討 した。Table 5 に算出結果を示す。組成計算で算出した 数值に対し，標準物質を用いた定量結果は，低めの数 值となっているが，メチルエステル換算の数值である 組成計算に対し，標準物質を用いた定量は遊離脂肪酸 換算であるため，メチルエステルと遊離脂肪酸の分子 量差を反映した結果となっていると考えられる。内部 標準物質 $(\mathrm{C} 17: 0)$ と同一の位置に妨害ピークが存在 する場合, 定量結果が不正確になるため, 内部標準無 添加のクロマトグラムを用いた補正の有無を比較した が, 補正有りの場合は補正なしに対して若干数值が高 くなることが確認された。この検討に用いたサンプル に打いては, 補正有無による数值の差は必ずしも大き なものではなかったが, ヘプタデカン酸を標準とする 場合，合同実験 2 の手法を基に，定量標準の補正を行 うことが望ましいと判断した。Table 6 に「内部標準補 正あり」の場合の検定後統計处理結果を示す。Cochran 検定によりいくつかの異常值が検出されたが, Dixon 検定で排除されたデータは無く，且つ合同実験 1 と比 較すると，いずれのサンプルでも室間再現性に改善が 認められた。改善の理由として, 合同実験 2 で統一化

Table 5 Total Trans-Fatty Acid Contents Measured by 10 Laboratories (2nd. Collaborative Experiment).

Table 5a $\mathrm{a}^{1)}$

\begin{tabular}{|c|c|c|c|c|c|c|c|c|c|c|c|c|c|c|c|}
\hline \multicolumn{6}{|c|}{ Sample ${ }^{4)}$} & \multicolumn{5}{|c|}{ Sample $^{4)}$} & \multicolumn{5}{|c|}{ Sample ${ }^{4)}$} \\
\hline & 1:0 & $20: 1$ & $10: 1$ & $5: 1$ & $0: 1$ & $1: 0$ & $20: 1$ & $10: 1$ & $5: 1$ & $0: 1$ & $1: 0$ & $20: 1$ & $10: 1$ & $5: 1$ & $0: 1$ \\
\hline Lab A & 2.66 & 4.54 & 6.33 & 9.39 & 45.76 & 2.65 & 4.52 & 6.27 & 9.33 & 45.24 & 2.90 & 4.92 & 6.84 & 10.24 & 49.07 \\
\hline Lab B & 1.75 & 3.73 & 5.53 & 8.42 & 44.36 & 1.74 & 3.70 & 5.49 & 8.31 & 44.01 & 1.86 & 4.08 & 5.87 & 9.09 & 48.00 \\
\hline Lab C & 2.13 & 3.54 & 4.92 & 7.53 & 42.43 & 2.12 & 3.52 & 4.90 & 7.50 & 42.17 & 2.28 & 3.88 & 5.36 & 8.34 & 49.93 \\
\hline Lab D & 2.58 & 4.56 & 6.28 & 9.52 & 44.81 & 2.56 & 4.53 & 6.23 & 9.44 & 44.38 & 2.87 & 5.12 & 7.03 & 10.39 & 49.40 \\
\hline Lab E & 2.27 & 4.66 & 6.15 & 8.52 & 35.89 & 2.26 & 4.62 & 6.10 & 8.47 & 35.60 & 2.72 & 5.06 & 6.88 & 10.32 & 49.24 \\
\hline Lab F & 2.37 & 4.12 & 5.75 & 8.51 & 44.16 & 2.37 & 4.12 & 5.75 & 8.51 & 44.16 & 2.46 & 4.34 & 6.00 & 9.20 & 48.90 \\
\hline Lab G & 2.45 & 4.42 & 6.12 & 8.92 & 44.07 & 2.43 & 4.39 & 6.09 & 8.87 & 43.80 & 2.51 & 4.49 & 6.20 & 9.16 & 49.51 \\
\hline Lab H & 2.11 & 2.91 & 5.54 & 8.55 & 41.99 & 2.11 & 2.91 & 5.54 & 8.55 & 41.99 & 2.28 & 3.25 & 5.69 & 9.22 & 46.05 \\
\hline Lab J & 1.79 & 3.69 & 5.33 & 8.39 & 45.75 & 1.79 & 3.64 & 5.28 & 8.28 & 45.15 & 1.84 & 3.81 & 5.56 & 8.76 & 47.52 \\
\hline Lab K & 2.78 & 4.74 & 6.46 & 9.53 & 45.94 & 2.76 & 4.71 & 6.41 & 9.45 & 45.55 & 2.97 & 5.08 & 6.93 & 10.29 & 49.38 \\
\hline Average & 2.29 & 4.09 & 5.84 & 8.73 & 43.51 & 2.28 & 4.07 & 5.81 & 8.67 & 43.20 & 2.47 & 4.40 & 6.24 & 9.50 & 48.70 \\
\hline Std.Dev. & 0.35 & 0.60 & 0.50 & 0.62 & 2.99 & 0.34 & 0.60 & 0.49 & 0.62 & 2.93 & 0.41 & 0.64 & 0.63 & 0.74 & 1.18 \\
\hline RSD & 15.2 & 14.8 & 8.6 & 7.2 & 6.9 & 15.1 & 14.7 & 8.5 & 7.1 & 6.8 & 16.5 & 14.6 & 10.1 & 7.8 & 2.4 \\
\hline
\end{tabular}

Table $5 b^{2)}$

\footnotetext{
${ }^{1)}$ Calculations made with correction by the internal standard

2) Calculations made without correction by the internal standard

3) Calculations measured as area $\%$ of the total fatty acid composition

${ }^{4)}$ Mixture of Rapeseed Oil and Hydrogenated Rapeseed Oil (w/w)
} 
した標準物質の添加方法（溶液として添加）に効果が あったと思われるが, 合同実験 1 に続いての検討であ るため, 参加各機関の操作熟練度が上がった要素もあ ると思われる。再現相関係数 $\left(\mathrm{CV}_{\mathrm{R}}\right)$ はトランス脂肪酸 含量約 $5 \mathrm{~g} / 100 \mathrm{~g}$ 以上の試料については $10 \%$ 以下とな り, 実分析に適用可能と判断した。含量 $5 \mathrm{~g} / 100 \mathrm{~g}$ 未満 の試料は $10 \%$ 以上の $\mathrm{CV}_{\mathrm{R}}$ が算出されたが, $\mathrm{AOCS}$ の合 同実験 ${ }^{8)}$ においても含量低位の試料については室間再 現性が悪い結果となって打り問題ないと判断した。

\section{$3 \cdot 5$ 合同実験 3}

合同実験 2 により, AOCS 法 ${ }^{8)}$ に準じた GC 条件でへ プタデカン酸を標準として問題ない検定結果が得られ たが, この条件は, $100 \mathrm{~m}$ の長いカラムを用いるため, 分析時間が長く, 且つ使用装置によってはガスクロマ トグラフの圧力上限值を超え, 最適流量が設定できな い可能性がある。また, カラムの種類を一種類に限定 すると, カラムの供給がなされなくなる場合等のリス クを負う。そこで, 合同実験 3 としてよりカラム長が 短く, また合同実験 1,2 と異なる液相を持つカラムを 用いた実験を行うこととした。カラムとしては TC-70 （ジーエルサイエンス製）を選択した，本カラムは AOCS Celf-96 $6^{7)}$ 記載の BPX-70 と同種の 70\%シアノプ ロピルポリシルフェニレンーシロキサン液相を有する ものである。合同実験にあたり, 取りまとめ機関がガ スクロマトグラフ条件を検討し, 得られた最適条件 （Table 3 Method b）にて実験を行った。標準物質扣よ び試料油脂サンプルは合同実験 2 と同様とした。デー タ取得は合同実験 2 と同様に内部標準添加を 2 連で, 内部標準無添加を 1 連で実施し, 定量標準の補正の有 無それぞれを算出するとともに, 組成による算出も 行った。Table 7 に算出結果, Table 8 に「内部標準補 正あり」の場合の検定後統計処理結果を示す。全試料
につき $10 \%$ 以下の $\mathrm{CV}_{\mathrm{R}}$ が算出され，良好な室間再現性 が得られた。また，カラム等の条件が異なる合同実験 2 と同様の数值が算出された。この結果をもって, 合同 実験に用いた 2 種類の液相からなるキャピラリーカラ ムを用いることで, 約 50 〜 $100 \mathrm{~m}$ のカラム長で実用的 な含量算出が可能と判断した。

\section{$3 \cdot 6$ 合同実験 4}

これまでの実験は主要な油脂産品であるなたねもし くは大豆油を用いた検討であるが，他の油脂への適用 を少数機関（4または 5 機関）にて確認した。

分析サンプルとして, パーム油，パーム核油，牛脂， 豚脂打よびこれらの水素添加油計 8 サンプルについて, 合同実験 2 扎よび合同実験 3 それぞれの条件にて分析 実施した。また，この際，合同実験 1 で検討した大豆 油およびその水素添加油の TC-70によるデータ取得も 行った。本検討は, クロマトグラムの分離状態確認を 主目的とし, 内部標準物質は用いず，結果は組成\%で 算出した。トランス脂肪酸ピークの同定は, これまで の大豆・なたねを参考とした。測定結果を Table 9 に 示す。少数機関による実験ではあるが, SP2560, TC70 いずれを用いた場合にもそれぞれのサンプルで各機関 同等の数值を得ることが出来た。この結果から, 今回 検討した分析条件は広い範囲の食用油に適用可能と判 断した。

\section{4 考察}

今回のわれわれの検討により，いわゆる「脂肪酸組 成分析」と同様の操作で, 油脂中のトランス脂肪酸含 量を簡便に測定できることが確認された。ただし，卜 ランス脂肪酸を含む油脂のクロマトグラムは各ピーク が近接するため, 安定した分離状態の維持, ピークの

Table 6 The Results of the Statistical Analysis after the Test in "the Presence of Correction by the Internal Standard" (2nd. Collaborative Experiment).

\begin{tabular}{lccccc}
\hline \multicolumn{1}{c}{ Sample } & \multicolumn{5}{c}{ Rapeseed / Hydrogenated Rapeseed (w/w) } \\
& $1: 0$ & $20: 1$ & $10: 1$ & $5: 1$ & $0: 1$ \\
\hline Total number of laboratories in a given assay & 8 & 10 & 9 & 8 & 9 \\
Total number of values in a given assay & 16 & 20 & 18 & 16 & 18 \\
Mean & 2.3 & 4.1 & 5.8 & 8.8 & 44.4 \\
Repeatability standard deviation $(\mathrm{Sr})$ & 0.020 & 0.096 & 0.050 & 0.070 & 0.588 \\
Repeatability coefficient of variation $(\mathrm{CVr})$ & 0.894 & 2.344 & 0.859 & 0.796 & 1.325 \\
Reproducibility standard deviation $\left(\mathrm{S}_{\mathrm{R}}\right)$ & 0.39 & 0.61 & 0.52 & 0.69 & 1.47 \\
Reproducibility coefficient of variation $\left(\mathrm{CV}_{\mathrm{R}}\right)$ & 16.79 & 14.85 & 9.01 & 7.81 & 3.32 \\
Repeatability value $(\mathrm{r})$ & 0.06 & 0.27 & 0.14 & 0.20 & 1.66 \\
Reproducibility value $(\mathrm{R})$ & 1.09 & 1.72 & 1.48 & 1.94 & 4.17 \\
\hline
\end{tabular}


Table 7 Total Trans-Fatty Acid Contents Measured by 10 Laboratories (3rd. Collaborative Experiment).

Table $7 \mathrm{a}^{1)}$

\begin{tabular}{|c|c|c|c|c|c|c|c|c|c|c|}
\hline \multicolumn{6}{|c|}{ Sample ${ }^{4)}$} & \multicolumn{5}{|c|}{ Sample $^{4)}$} \\
\hline & 1:0 & $20: 1$ & $10: 1$ & $5: 1$ & $0: 1$ & $1: 0$ & $20: 1$ & $10: 1$ & $5: 1$ & $0: 1$ \\
\hline Lab A & 2.89 & 4.65 & 6.19 & 9.00 & 44.44 & 2.86 & 4.59 & 6.11 & 8.89 & 43.92 \\
\hline Lab B & 2.75 & 4.40 & 5.90 & 8.62 & 43.19 & 2.74 & 4.37 & 5.87 & 8.55 & 42.86 \\
\hline Lab C & 2.67 & 4.18 & 5.47 & 7.97 & 39.51 & 2.65 & 4.14 & 5.43 & 7.92 & 39.18 \\
\hline Lab D & 2.87 & 4.65 & 6.19 & 8.87 & 42.88 & 2.84 & 4.62 & 6.14 & 8.80 & 42.49 \\
\hline Lab E & 2.81 & 4.56 & 6.09 & 8.67 & 43.03 & 2.80 & 4.53 & 6.04 & 8.61 & 42.71 \\
\hline Lab F & 2.52 & 4.11 & 5.51 & 8.09 & 43.42 & 2.50 & 4.08 & 5.48 & 8.04 & 43.16 \\
\hline $\mathrm{Lab} G$ & 2.73 & 4.46 & 6.02 & 8.90 & 43.52 & 2.72 & 4.43 & 5.96 & 8.84 & 43.24 \\
\hline Lab H & 2.52 & 3.52 & 5.32 & 8.24 & 41.28 & 2.52 & 3.52 & 5.32 & 8.16 & 40.89 \\
\hline Lab J & 3.40 & 5.08 & 6.44 & 9.53 & 43.94 & 3.46 & 5.05 & 6.41 & 9.46 & 43.60 \\
\hline Lab K & 2.84 & 4.84 & 6.37 & 9.20 & 44.51 & 2.82 & 4.80 & 6.31 & 9.11 & 44.09 \\
\hline Average & 2.80 & 4.45 & 5.95 & 8.71 & 42.97 & 2.79 & 4.41 & 5.91 & 8.64 & 42.61 \\
\hline Std.Dev. & 0.25 & 0.43 & 0.39 & 0.50 & 1.52 & 0.27 & 0.43 & 0.38 & 0.49 & 1.51 \\
\hline RSD & 8.9 & 9.8 & 6.6 & 5.7 & 3.5 & 9.6 & 9.6 & 6.4 & 5.6 & 3.5 \\
\hline
\end{tabular}

1) Calculations made with correction by the internal standard

${ }^{2)}$ Calculations made without correction by the internal standard

3) Calculations measured as area \% of the total fatty acid composition

4) Mixture of Rapeseed Oil and Hydrogenated Rapeseed Oil (w/w)

Table 8 The Results of the Statistical Analysis after the Test in "the Presence of Correction by the Internal Standard" (3rd. Collaborative Experiment).

\begin{tabular}{lccccc}
\hline \multirow{1}{*}{ Sample } & \multicolumn{4}{c}{ Rapeseed / Hydrogenated Rapeseed (w/w) } \\
& $1: 0$ & $20: 1$ & $10: 1$ & $5: 1$ & $0: 1$ \\
\hline Total number of laboratories in a given assay & 9 & 10 & 10 & 10 & 9 \\
Total number of values in a given assay & 18 & 20 & 20 & 20 & 18 \\
Mean & 2.7 & 4.4 & 5.9 & 8.7 & 43.4 \\
Repeatability standard deviation (Sr) & 0.025 & 0.087 & 0.048 & 0.090 & 0.255 \\
Repeatability coefficient of variation $(\mathrm{CVr})$ & 0.934 & 1.957 & 0.810 & 1.028 & 0.589 \\
Reproducibility standard deviation $\left(\mathrm{S}_{\mathrm{R}}\right)$ & 0.14 & 0.44 & 0.39 & 0.50 & 0.99 \\
Reproducibility coefficient of variation $\left(\mathrm{CV}_{\mathrm{R}}\right)$ & 5.15 & 9.90 & 6.61 & 5.75 & 2.28 \\
Repeatability value (r) & 0.07 & 0.25 & 0.14 & 0.25 & 0.72 \\
Reproducibility vaiue $(\mathrm{R})$ & 0.40 & 1.25 & 1.11 & 1.42 & 2.80 \\
\hline
\end{tabular}

同定，ピークの積分条件決定などに技術的に難しい要 素を含む。今回の合同実験に扔いて，実験を繰り返す ごとに室間再現性は向上していく傾向が見られた。こ れは，実験の中で，手法の確立がなされたことを示す が，各担当者の熟練度が向上した要素もあると思われ る。

また，今回の検討条件においても，予想される脂肪 酸ピークすべての完全分離はなされないため, クロマ トグラム中のいずれかにピークの重なりが生じる可能 性がある。ピークの重なりは, 測定対象油脂が持つ脂
Table $7 \mathrm{c}^{3)}$

\begin{tabular}{lcccc}
\hline \multicolumn{5}{c}{ Sample $^{4)}$} \\
$1: 0$ & $20: 1$ & $10: 1$ & $5: 1$ & $0: 1$ \\
\hline 2.99 & 4.82 & 6.63 & 9.37 & 46.12 \\
2.87 & 4.73 & 6.25 & 9.16 & 45.59 \\
3.09 & 5.01 & 6.62 & 9.56 & 45.56 \\
3.03 & 4.96 & 6.63 & 9.53 & 45.87 \\
2.95 & 4.71 & 6.35 & 9.31 & 46.08 \\
2.52 & 4.18 & 5.65 & 8.35 & 46.22 \\
3.07 & 4.74 & 6.43 & 9.28 & 46.27 \\
2.64 & 3.76 & 5.88 & 8.58 & 45.10 \\
2.88 & 4.81 & 6.51 & 9.69 & 45.72 \\
2.91 & 4.85 & 6.47 & 9.53 & 45.65 \\
\hline 2.90 & 4.66 & 6.34 & 9.24 & 45.82 \\
0.18 & 0.39 & 0.33 & 0.44 & 0.37 \\
6.4 & 8.3 & 5.2 & 4.7 & 0.8 \\
\hline
\end{tabular}


Table 9 Total Trans-Fatty Acid Contents in Various Oils and Fats (4th. Collaborative Experiment).

Table 9a (SP2560)

\begin{tabular}{lccccccc}
\hline & Lab A & Lab B & Lab C & Lab K & Average & StdDev & RSD \\
\hline Palm & 0.77 & 0.65 & 0.57 & 0.84 & 0.71 & 0.12 & 16.9 \\
Hydrogenated palm & 20.04 & 19.71 & 18.05 & 19.79 & 19.40 & 0.91 & 4.7 \\
Pork fat & 2.02 & 1.70 & 1.67 & 2.19 & 1.90 & 0.25 & 13.2 \\
Hydrogenated pork fat & 26.38 & 24.17 & 24.74 & 25.98 & 25.32 & 1.04 & 4.1 \\
Palm kernel oil & 0.00 & 0.00 & 0.00 & 0.09 & 0.02 & 0.05 & 250.0 \\
Hydrogenated palm kernel & 7.50 & 7.15 & 6.49 & 7.36 & 7.13 & 0.45 & 6.3 \\
Beef tallow & 4.88 & 4.63 & 4.12 & 4.71 & 4.59 & 0.33 & 7.2 \\
Hydrogenated beef tallow & 26.71 & 25.79 & 25.15 & 26.60 & 26.06 & 0.73 & 2.8 \\
\hline
\end{tabular}

Table 9b (TC70)

\begin{tabular}{lcccccccc}
\hline & Lab A & Lab B & Lab C & Lab H & Lab K & Average & StdDev & RSD \\
\hline Palm & 0.93 & 0.78 & 0.84 & 0.52 & 0.67 & 0.75 & 0.16 & 21.3 \\
Hydrogenated palm & 18.21 & 18.93 & 19.47 & 16.50 & 19.34 & 18.49 & 1.22 & 6.6 \\
Pork fat & 2.02 & 1.89 & 2.04 & 1.37 & 2.25 & 1.91 & 0.33 & 17.3 \\
Hydrogenated pork fat & 24.09 & 21.09 & 24.72 & 23.91 & 25.08 & 23.78 & 1.58 & 6.6 \\
Palm kernel oil & 0.16 & 0.12 & 0.08 & 0.00 & 0.08 & 0.09 & 0.06 & 66.7 \\
Hydrogenated palm kernel & 6.85 & 7.62 & 6.84 & 6.67 & 6.88 & 6.97 & 0.37 & 5.3 \\
Beef tallow & 4.43 & 4.14 & 4.09 & 3.07 & 4.49 & 4.04 & 0.57 & 14.1 \\
Hydrogenated beef tallow & 23.97 & 23.83 & 23.91 & 23.34 & 24.87 & 23.98 & 0.55 & 2.3 \\
Soybean & 2.48 & 2.43 & 2.44 & 2.24 & 2.54 & 2.41 & 0.13 & 5.2 \\
Hydrogenated soybean & 39.96 & 43.64 & 40.66 & 36.86 & 40.56 & 40.43 & 2.78 & 6.9 \\
\hline
\end{tabular}

C20：1 メチルエステルの主要マススペクトルイオンで ある $\mathrm{m} / \mathrm{z}=324,292,250$ のピーク混在が確認された ため，このカラムを用いた場合， C20： $1 t$ は C18： $3 t$ 群 と合わせてトランス脂肪酸と算出されていると考えら れる。これに対し, 合同実験 3 に用いた TC-70の場合, $\mathrm{C} 20 ： 1 t$ は独立して検出された。

$\mathrm{GC}$ 条件は, SP2560の場合, C20：1c と C18：3ccc の分離が, TC-70 の場合, $\mathrm{C} 18: 3 c c c$ と $\mathrm{C} 20: 0$ が分離 する条件に設定した。これらピークはカラム液相の特 性により大変近接して扔り, ピーク分離状態を確認す る指標として有効である。今回の実験では大きな問題 とならなかったが，合同実験に扔いて，同一ロットの カラムを用い， GC 条件を統一したにもかかわらず，各 機関のクロマトグラムに打いて，上記のピーク分離は 全く同様ではなかった。これを受けて, 基準油脂試験 法制定に当たっては GC 条件については完全に固定せ ず，今回の $\mathrm{GC}$ 条件を前提に, 最適ピーク分離が得ら れる条件を各使用者が設定するスタイルにすることが 望ましいと判断した。

今回の実験に打いては，トランス脂肪酸の高分離を 意図して，昇温分析ではなく，恒温分析をメソッドと して設定した。脂肪酸分析を連続で行う場合, 次の分
析に妨害ピークが出現する影響を排除するため, 多く の油脂で存在が予想される $\mathrm{C} 24: 1$ までを溶出させてお く必要があるが, とくにカラム長が長い場合恒温分析 では溶出までに長時間を要する。そこで，トランス脂 肪酸ピーク溶出後に昇温を取り入れると, 分析時間短 縮と, 以後の測定に打ける妨害ピーク排除を行うこと ができる。今回の検討でSP2560を用いた場合には， C22 溶出後, オーブン温度をカラム耐熱上限以下まで 上げる操作を取り入れている。

内部標準物質としてはへプタデカン酸を基準油脂試 験法に提案することとした。へプタデカン酸は多くの 油種で確認されるため, 今回検討のように, 内部標準 無添加のクロマトグラムも取得し, 補正を行うことが 原則であると思われる。

内部標準を用いた定量計算に加え，今回，脂肪酸組 成分析で用いられる組成\%による算出も併せて検討し た。実験の結果，定量計算と組成\%には，理論上想定 される幅とほぼ等しい数值乘離が確認された。トラン ス脂肪酸の含量分析という視点からは, 内部標準を用 い, 油脂食品全体の中のトランス脂肪酸を算出すべき であるが, 組成計算においても, 精度は同様に安定し ているため, 工程管理等に扔いては, 組成計算も併用 
可能であると思われる。

\section{5 総括}

基準油脂試験法設定を目的として，トランス脂肪酸 含量約 $2 \mathrm{~g} / 100 \mathrm{~g} \sim 45 \mathrm{~g} / 100 \mathrm{~g}$ の試料を用い, キャピ ラリー GC 法による合同実験を行った。 その結果,

1）内部標準物質として, ヘプタデカン酸 $(\mathrm{C} 17: 0)$ が好適と考えられた。

2) SP2560 (100 m) カラム（100\%シアノプロピルポ リシロキサン液相)，TC-70（60 m） カラム（70\% シアノプロピルポリシルフェニレンーシロキサン 液相）の 2 種類のカラムで合同実験を行い，それ ぞれで同等の数值を得た。また室間再現性は $\mathrm{CV}_{\mathrm{R}}$ <10\%と良好であった。

3）油種として, 大豆, なたね, パーム, パーム核, 牛脂, 豚脂, およびこれらの水素添加油を実験に 供し，いずれも良好な分離が得られた。

以上から, 魚油・乳脂を除外する食用油脂に関し, 今回検討の手法は油脂中のトランス脂肪酸含量算出に 適していると判断した。

\section{References}

1. Zock, P.L.; Katan, M.B. Trans fatty acids, lipoproteins, and coronary risk. Can. J. Physiol. Pharmacol. 75, 211-216 (1997).

2. Mozaffarian, D.; Katan, M.B.; Ascherio, A.; Stampfer, M.J.; Willett, W.C. Trans fatty acids and cardiovascular disease. N. Engl. J. Med. 354, 1601-1613 (2006).

3. Department of Health and Human Services, Food and Drug Administration, Food labeling: Trans fatty acids in nutrition labeling, nutrient content claims, and health claims. Federal Register. 68, (133) 21 CFR Part 101 (2003).
4. Stender, S.; Dyerberg, J. The Influence of Trans Fatty Acids on Health, 4th edn. The Danish Nutrition Council, pp.45-51 (2003).

5. Health Canada, It's Your Health-Trans Fat. http://www.hc-sc.gc.ca/iyh-vsv food-aliment/trans_e. html

6. Food Safety Commission of the Cabinet Office, Fact Sheet on Trans Fatty Acid. http://www.fsc.go.jp/sonota/transfattyacids1902.html

7. Determination of cis- and trans- fatty acids in hydrogenated and refined oils and fats by capillary GLC. AOCS Official Method Ce 1f-96 (2002).

8. Determination of cis-, trans-, saturated, monounsaturated and polyunsaturated fatty acids in vegetable or non-ruminant animal oils and fats by capillary GLC. AOCS Official Method Ce 1h-05 (2005).

9. Fat (total, saturated, and unsaturated) in food. $A O A C$ Official Method 996.06, (2001).

10. Preparation of methyl esters of fatty acids (boron trifluoride-methanol method). Standard Methods for the Analysis of Fats, Oils and RelatedMaterials (Japan Oil Chem. Soc. ed.). 2.4.1.2-1996 (1996).

11. Duchateau, G.S.M.J.E.; Oosten, H.J.V.; Vasconcellos, M.A. Analysis of cis- and trans-fatty acid isomers in hydrogenated and refined vegetable oils by capillary gas-liquid chromatography. J. Am. Oil Chem. Soc. 73, 275-282 (1996).

12. Ratnayake, W.M.N.; Plouffe, L.J.; Pasquier, E.; Gagnon, C. Temperature-sensitive resolution of cis- $^{-}$and transfatty acid isomers of partially hydrogenated vegetable oils on SP2560 and CP-Sil 88 capillary columns. J. AOAC Int. 85, 1112-1118 (2002).

13. Standard Methods for the Analysis of Fats, Oils and RelatedMaterials (Japan Oil Chem. Soc. ed.). Kyo41996, pp.1-12 (1996). 